\title{
Narrative Concepts in the Study of Eighteenth-Century Literature
}

\section{Contents}

Liisa Steinby and Aino Mäkikalli (University of Turku)

Introduction:

The Place of Narratology in the Historical Study of Eighteenth-Century Literature

Michael McKeon (Rutgers University)

The Eighteenth-Century Challenge to Narrative Theory

John Richetti (University of Pennsylvania)

Formalism and Historicity Reconciled in Henry Fielding's Tom Jones

Monika Fludernik (University of Freiburg)

Perspective and Focalization in Eighteenth-Century Descriptions

Aino Mäkikalli (University of Turku)

Temporality in Aphra Behn's Oroonoko and Daniel Defoe's Robinson Crusoe

Liisa Steinby (University of Turku)

Temporality, Subjectivity and the Representation of Characters in the Eighteenth-Century

Novel: From Defoe's Moll Flanders to Goethe's Wilhelm Meisters Lehrjahre

Dorothee Birke (University of Freiburg)

Authorial Narration Reconsidered: Eliza Haywood's Betsy Thoughtless, Anonymous's

Charlotte Summers, and the Problem of Authority in the Mid-Eighteenth-Century Novel

Karin Kukkonen (University of Oslo)

Problems of Tellability in German Eighteenth-Century Criticism and Novel-Writing

Claudia Nitschke (University of Durham)

Immediacy: The Function of Embedded Narratives in Wieland's Don Sylvio

Christine Waldschmidt (University of Mainz)

The Tension between Idea and Narrative Form: The Example as a Narrative Structure in

Enlightenment Literature

Penny Pritchard (University of Herthfordshire) 
'Speaking Well of the Dead': Characterization in the Early Modern Funeral Sermon

Pat Rogers (University of South Florida)

The Use of Paratext in Popular Eighteenth-Century Biography: The Case of Edmund Curll

Teemu Ikonen (University of Tampere)

Peritextual Disposition in French Eighteenth-Century Narratives 


\title{
Problems of Tellability in German Eighteenth-Century Criticism and Novel-Writing
}

\author{
Karin Kukkonen ${ }^{1}$
}

'My God, said the Duchess. I am pregnant. Who done it?' Marie-Laure Ryan cites this mockformula of French bestsellers in her entry on 'tellability' in The Routledge Encyclopedia of Narrative (Ryan, 2005, p. 590). What makes a narrative worth telling, it suggests tongue-incheek, are religion, aristocracy, sex and mystery. The formula illustrates how tellability depends on the subject matter of the narrative. Ryan points out that such salience can be, on the one hand, grounded in universally relevant topics (such as sex and death) and, on the other hand, be related to cultural contexts (for example the interest in the exploits of aristocrats seems to be tied more particularly to seventeenth- and eighteenth-century Western literature). Narratology presents 'tellability' as a concept for what allows us to judge the story: Can it ward off the question 'so what?' However, the strategies with which the narrative prevents readers from asking this particular question move beyond pregnant duchesses. It can also depend on the rhetorical skill of the narrator in capturing the attention of the reader, the unexpectedness of events and their logical complexity (in the plot), as well as the general fascination with particular topics or particular settings and characters (see Baroni, 2014).

The roots of 'tellability' in narratology lie in research on oral storytelling, where the storyteller is constantly subject to the feedback of the listeners, as formalized in the 'so what?' question (first discussed by Labov, Storytelling in the Inner City). Indeed, most of the defining features of 'tellability' have been developed on oral storytelling rather than literary narratives (see Labov, 1972; Ochs and Capps, 2001; Norrick, 2005), as well as professional storytelling in legal and journalistic contexts (see Baroni, 2009) and short story structures (see Ryan, 1991). ${ }^{2}$ Monika Fludernik's influential discussion of the tellability that arises from narrative's capacity to capture experience also depends on her engagement with the 'natural narratives' of oral storytelling (Fludernik, 1996). As Ryan reminds us, 'high literature often makes art out of

\footnotetext{
${ }^{1}$ Acknowledgements. I would like to thank Raphaël Baroni for his comments on a previous version of this article, Liisa Steinby for sharing her expertise in eighteenth-century German literature and Aino Mäkikalli for her editorial work. My research was funded by an Academy of Finland Postdoctoral Grant.

${ }^{2}$ A salient exception to this trend is Mary Louise Pratt, who connects conversational analysis and literary theory (rather than narratology) in Toward a Speech Act Theory of Literary Discourse (1977).
} 
the non-tellable, thereby following in the footsteps of Flaubert, who claimed that Madame Bovary was a "novel about nothing"' (Ryan, 2005, p. 590).

Writing a novel about 'nothing' in the eighteenth century would be a decidedly trivial enterprise, and certainly not a feature that an author would brandish about as Flaubert does. Literature was meant to contribute to a learning process about the social world, its hidden workings and underlying order, that provides both emotional and intellectual pleasures to readers. In the terms of the Horatian formula, literature was meant to delight and instruct ('aut prodesse aut delectare'). In order to fulfil these functions, as the critics in the eighteenth century knew very well, the narrative has to capture readers' attention. For Johann Jakob Breitinger (and a few other critics of the German-speaking countries in the eighteenth century), the 'marvelous' contributes to a narrative's tellability, because it captures readers' attention and ensures their enjoyment of the narrative. Breitinger states in Kritische Dichtkunst (1966 [1740]), 'der Poet durch das Wunderbare in seinen Erzehlungen die Aufmercksamkeit und die Verwunderung des Lesers beständig unterhalten muß' (Breitinger, 1966, p. 342). ${ }^{3}$ For Breitinger (and other critics of the German-speaking countries in the eighteenth century), the 'marvelous' leads to a narrative's tellability, because it captures readers' attention and ensures their enjoyment of the narrative. At the same time, however, it also needs to be embedded in the general probability of the text. Where the boundaries between the marvelous and the probable run was the subject of fierce debates in the Germanspeaking countries in the eighteenth century, which we shall revisit in the following section.

Approaching the concept of 'tellability' through these debates on the marvelous and the probable allow us to connect 'tellability' with a tradition in literary criticism that reaches back to Aristotle. ${ }^{4}$ At the same time, it also helps us develop tellability further as a concept, in particular with respect to three issues: First, tellability is usually discussed in terms of a minimum threshold (how much excitement do you need to make a narrative tellable?). The tension between the marvelous and the probable, on the other hand, reminds us to take into account both the lower and the upper limits of tellability. Second, narratology limits tellability to the diegesis of the narrative (what is being told, see Baroni, 2014). As the historical shift of what makes a story tellable in the period we consider here (1730-1774) shows, however, not

\footnotetext{
3 'The poet has to keep up the attention and the puzzlement of readers through the marvelous in his narratives'. Unless noted otherwise, this and the following translations are mine. Throughout, the German texts are kept intact with their original eighteenth-century spellings.

${ }^{4}$ Throughout the article, I translate 'wunderbar' with 'marvelous' and 'Wahrscheinlichkeit' with 'probability'. These are the corresponding terms found in seventeenth- and eighteenth-century English criticism for these concepts. For an accessible demonstration of these terms and debates, see 'The Wonderfully Long Chapter on the Marvelous' in Henry Fielding's Tom Jones.
} 
only the events in the story but also the psychological development of the characters (existants in the diegesis) contribute to tellability. Third, Jerome Bruner's notion of 'canonicity and breech' is introduced both by Ryan and Baroni as a specification of tellability. According to Bruner, a narrative has to draw on established scripts of action, but at the same time, it needs to break these scripts for the narrative to gain its 'point', to become tellable (Bruner, 1991). Drawing on Aristotle's notion of 'improbable probability' (and its treatment in the eighteenth century), we discover the metafictional dimension of tellability's treatment of scripts and conventions.

But before we move into the worlds of the marvelous and the probable, I need to correct my claim from earlier that no eighteenth-century author would advertise that they are writing a novel about 'nothing'. The Austrian writer Maria Anna Sagar (1727-1805) entitles her second novel Karolinens Tagebuch; ohne ausserordentliche Handlungen, oder gerade so viel als gar keine (2013 [1774]). As the preface informs us in an impish tone, this might reflect the honesty of the author that, as a woman writer from the provincial backwaters of Bohemia ('böhmisches Frauenzimmer'), she really has nothing of interest to say. Or, she continues, perhaps it is a ploy on her part to make readers curious about how she is going to fill the three hundred pages of her book with 'nothing'. What Sagar chooses to do with her three hundred pages is roughly the following: Young Karoline writes a set of letters to her sister Nanette and to her writing master Herr Cyrili. As the bride of Karl, she traces her own emotional states with the wedding approaching, while at the same time, she sets out to recount the more adventurous tale of her friend Eleonora Lusani. Eleonora is abducted and put in the care of the mysterious Duchess of *** in order to protect her from the rakish duke, and she hears the duchess's story of her unhappy marriage, separation from her son and how she finally managed to reunite with him. Throughout the novel, Nanette and Herr Cyrili critique the probability of these letters and question in how far they help Karoline in her attempts to put her thoughts into order. Luckily, Karoline is no Emma Bovary, and the project of literary education succeeds in the end. Karolinens Tagebuch is steeped in the contemporary critical debates that I have outlined above, and Sagar plays with the conventions of tellability as they were in the process of getting established for the novel. In what follows, instances from Karolinens Tagebuch shall accompany the more theoretical discussions of eighteenth-century takes on tellability.

\footnotetext{
${ }^{5}$ Karoline's Diary, without extraordinary events, or just about none at all.
} 


\section{Tellability, Marvelous and Probable}

According to Aristotle, mimesis makes a fictional narrative pleasurable for its audience because we take delight in imitations (Aristotle, 1996, p. 6). How exactly this imitation of nature should work for a successful narrative was the subject of seemingly never-ending debates in neoclassical criticism. A properly European project, neoclassical criticism begins with the extensive elaborations on Aristotle's Poetics which Castelvetro, Vida and Scaliger provided in the sixteenth century, became the dominant critical discourse in seventeenthcentury France and Britain, and was renegotiated within the tension between Enlightenment rationality and sentiment that arose in eighteenth-century France, Britain, and eventually Germany (see Kukkonen, 2015 for an overview). By that time, around 1730, the notion of 'probability' (Wahrscheinlichkeit) had been established as the key concept for mimesis in neoclassical criticism (see Bray, and Kremer for France and Patey for Britain). Probability is not the same as reality. Instead, it shapes reality in such a way that it becomes interesting, pleasing and instructive for readers, while yet remaining credible. A narratologist might rephrase this as 'probability makes narratives tellable' today. There is a lot more to probability than just tellability, but we shall focus on the overlap between the two concepts here and follow our present purpose to let the eighteenth century speak back to the twenty-first.

In the 1740 s, the German-Swiss relations in the world of letters were shaken, when the Swiss critics Johann Jakob Bodmer and Johann Jakob Breitinger took up their quills and responded to the German critic Johann Christoph Gottsched. While the strict Gottsched seemed to tie literature down to a dull correspondence to the real world, the Swiss stressed the freedom of the imagination and liberated literature to explore possible worlds. This is the potted narrative which is often told of the controversy conducted between Gottsched's Versuch einer kritischen Dichtkunst (2003 [1730]), Bodmer's Kritische Abhandlung von dem Wunderbaren in der Poesie und dessen Verbindung mit dem Wahrscheinlichen (1740), Breitinger's Kritische Dichtkunst (1740) and Gottsched's second edition of Versuch einer kritischen Dichtkunst (1751). Lubomìr Doležel, for example, highlights Breitinger's Kritische Dichtkunst, certainly the most rewarding of the three treatises, as the point at which European poetics moves from the notion that literature imitates in correspondence with nature to the idea that the poet transforms possible worlds into worlds that have 'the appearance and the name of reality' (Doležel, 1990, p. 42; English version by Doležel). For our purposes, however, it is useful to take a broader view of the debate.

Gottsched's Versuch einer Critischen Dichtkunst is part of the larger programme for promoting literary culture in the German-speaking countries, which he pursued together with 
his wife Luise Gottsched (see Goodman, 2005 and Brown, 2012), and which included the publication of a literary journal (Die Vernünftigen Tadlerinnen, 1725-1726), a repository of German translations of established pieces for the theatre (Die Deutsche Schaubühne, 17411745) and a new standard grammar for German (Deutsche Sprachkunst, 1748). Versuch einer Critischen Dichtkunst, in turn, is meant to lay the foundations of German literary criticism. In particular, Gottsched sets out to define what literature is and what functions it should fulfil. He writes, 'Die Fabel ist nichts als eine Nachahmung der Natur. Denn wenn eine Fabel nicht wahrscheinlich ist, so taugt sie nichts' (Gottsched, 2003, p. 33). ${ }^{6}$ Gottsched's use of the term 'Fabel' evokes the literary genre of the fable (which according to him is the essential genre of literature that carries a moral message), as well as the notion of what we would call 'plot' today. Does the fable have to be 'probable' with respect to its reference of reality? As Sarah Ruth Lorenz (2014) points out, Gottsched's Critische Dichtkunst runs into trouble at this point, because even though Gottsched pursues the notion that literature should imitate nature, at the same time, he also privileges the fable where animals can talk and other improbable things happen. According to Lorenz, Gottsched's forms are constantly shifting between probability as something which can happen in the real world and the potentially fantastic probability of the narrative that aims to instruct. This reflects Gottsched's struggle to devise a literary theory based on probability which supports Enlightenment ideals of instruction.

At the same time, I think, Gottsched indicates - in slightly garbled form - a connectedness between the plot (understood as the arrangement of events in the narrative) and the referentiality to reality. Gottsched, as well as Bodmer and Breitinger, tends to describe the mimesis of literature in terms of painting in the 'ut pictura poesis'-tradition, which had a long history at this point (see Hagstrum, 1968; see Kowalik, 1992, pp. 62-86 for Breitinger's indebtedness to Dubos in particular). Like a good painter, the poet represents reality as faithfully as possible. However, poets also make changes to heighten the interest of readers in reality. In fact, as Breitinger points out, it is the artistic nature of the representation which leads readers to pay attention to things copied that they would ignore in reality ('Die Copie ziehet uns stärcker an sich, als das Original', p. 72). However, the things copied are not only representations of items and characters from reality, but also - true to Aristotle's definition the actions of the characters. As Gottsched puts it, 'Ein Poet ahmet hauptsächlich die Handlungen der Menschen nach' (Gottsched, 2003, p. 48), ${ }^{7}$ and the imitation of these actions unfolds through the plot of the narrative. Hence, the fable can be probable, even with its

\footnotetext{
6 'Plot is an imitation of nature, since if a plot is not probable, it is no good'.

7 'The poet imitates mainly the actions of men'.
} 
speaking animals, because it imitates the (typical) actions of men (see also Waldschmidt in this volume for eighteenth-century debates around the fable).

Probability, as the designed imitation of neoclassical criticism, unfolds both on the level of the fictional world (and its degree of correspondence to reality) and on the level of the plot (and its arrangement of events). Drawing on the neoclassical debates (and contemporary cognitive approaches), I have suggested elsewhere that we can think of a narrative's 'probability design' in terms of a feedback loop between the plot and the vraisemblance of the fictional world (that is, what we think its likely state of affairs; see Kukkonen, 2014). As the narrative progresses, readers' probability judgements for the fictional world develop according to the events and the information that the plot reveals. None of the neoclassical critics would have put the relationship in these terms, but when Gottsched writes that 'Wahrscheinlichkeit' ensures 'die Übereinstimmung der Fabel mit der Natur' (Gottsched, 2003, p. 129), ${ }^{8}$ we can read 'fable' both in terms of the plot and in terms of the fictional world.

Contrary to common prejudice, Gottsched admitted that a probable narrative can feature marvelous elements ('lauter neue, seltsame und fürtreffliche Sachen', p. 104), but these need to be carefully integrated into the overall narrative (Gottsched, 2003, pp. 115, 122). As Gottsched puts it, 'Ein heutiger Poet hat also grosse Ursache, in dergleichen Wunderdingen sparsam zu sein' (Gottsched, 2003, p. 115). ${ }^{9}$ He does not ask for the exclusion of the marvelous, but for its judicious application to the purposes of narrative. One of the poets who, according to Gottsched, went overboard with the marvelous is John Milton in his Paradise Lost. Bodmer writes his Kritische Abhandlung explicitly to come to the rescue of Milton and to highlight the value of Paradise Lost, following and extending Joseph Addison's series of essays on Milton in The Spectator. Bodmer defends Milton's use of marvelous elements in the epic poem, explaining for example, why Milton was justified to present the immaterial angels as having bodies (and moreover bodies that can bleed), why Milton did not fail probability when he presents Pandemonium as too small for the entire host of Satan, and why Milton had every poetic right to introduce pagan gods and personalizations like Sin for allegorical purposes. In the second edition of his Versuch einer Kritischen Dichtkunst, Gottsched responds to Bodmer and adds comments that explicitly argue against Milton, stressing that the English poet fails to achieve probability in his epic (see for example the notes referencing the 1751 edition in Gottsched, 2003, pp. 50, 78, 114).

\footnotetext{
8 'The fabel matches nature'.

9 'Poets today have good reason to use the marvelous but sparingly'.
} 
While Gottsched and Bodmer disagree profoundly on the value of Milton's Paradise Lost, they also perform a critical debate through the shared vocabulary of

'Wahrscheinlichkeit' (probability), 'das Wunderbare' (the marvelous) and 'Natur' (nature). Indeed Gottsched acknowledges a key point of Bodmer and Breitinger: 'Dem Dichter stehen nun alle möglichen Welten zu Diensten' (Gottsched, 2003, p. 89 FN). ${ }^{10}$ But while the poet can employ any possible world she likes, Gottsched stresses, she also needs to make sure that it still remains probable ('wahrscheinlich'). In turn, Bodmer agrees that 'Wahrscheinlichkeit' is crucial for the successful poem. However, neither Gottsched nor Bodmer provide a convincing and clear definition of the relation between the marvelous and probability. Instead, if we read their arguments for or against Milton, the controversy soon seems to approach the level of farce. ${ }^{11}$

Breitinger's Kritische Dichtkunst provides a more systematic engagement with 'das Wunderbare', 'Wahrscheinlichkeit' and 'Natur', and he spells out some of the assumptions which were more implicit in Gottsched and Bodmer (for general introductions to Breitinger, see Bender, 1973 and Zelle, 2009). Breitinger defines the work of the poet as follows: 'Sein ganzes Vermögen besteht in der geschickten Verbindung des Wunderbaren mit dem Wahrscheinlichen; Dieses erwirbt seiner Erzehlung Glauben, jenes verleihet ihr eine Kraft, die Aufmerksamkeit des Lesers zu erhalten, und eine angenehme Verwunderung zu gebähren’ (Breitinger, 1966, pp. 298-99). ${ }^{12}$ The marvelous is necessary for the attention of the reader and for the pleasure of reading, but (and Breitinger mentions this first), it also needs to remain credible. According to Breitinger, the marvelous does not just arise out of unusual personages like Milton's angels. Instead, he stresses that 'Das Ergezen ist also zweyfach, das erste entstehet eigentlich von der Materie der Nachahmung, das andere von der Kunst der

\footnotetext{
10 'The poet can draw on all possible worlds'. (This remark was added in the 1751 edition).

${ }^{11}$ Let us take as our example their responses to Voltaire's observation that Paradise Lost lacks in probability, because Pandemonium is not big enough for all of Satan's host (see his Essai sur la poésie épique, especially pp. 339-43). Gottsched repeats Voltaire's charge, asking whether the demons need to turn into dwarfs in order to enter it. Bodmer, on the other hand, stresses that only Satan's war council would need to find space in it. Breitinger indicates that he has little patience with such debates, and arguments around questions such as whether all the damned angels can fit Pandemonium or whether angels can bleed (also discussed in both Gottsched and Bodmer) that are so far removed from today's concerns of literary theory that they are easily mocked. Note, however, that these examples serve to indicate roughly where the boundaries between the marvelous and the probale run for the two critics. Gottsched has a more limited notion of the marvelous. Hence Milton's angels are too much, and he saddles them with another marvelous transformation in order to stress the absurdity. Bodmer, with his more capatious notion of the marvelous, thinks that Milton's angels are still probable and hence he finds the more probable explanation of the smaller group. Even though they draw the boundaries differently, both critics work on the same overall (Aristotelian) model.

12 'All the poet's capability lies in the skillful connection of the marvelous and the probable; the former gives credibility to the narrative, the latter gives it the force to maintain the attention of readers and to give birth to pleasant wonder'.
} 
Nachahmung, ${ }^{13}$ (Breitinger, 1966, p. 71; see also pp. 292-93). In other words, the tellability of the marvelous does not just arise from the subject matter, but also from the construction of the narrative. Breitinger defines the marvelous in terms not dissimilar from today's narratologists define tellability: 'Je neuer demnach, je unbekannter, je unerwarteter eine Vorstellung ist, desto grösser muß auch das Ergetzen seyn' (Breitinger, 1966, p. 112). ${ }^{14}$ Such tellability can be due to the inherent strangeness of the idea, or, indeed, due to the fact that the mind of the reader has not had the opportunity to engage with the marvelous object before (Breitinger, 1966, p. 124). Breitinger gives the notion that tellability can be due to contextual features an Enlightenment spin, when he approaches it with the assumption that texts engage readers' minds and lead them to greater insight into the principles of the world.

According to Breitinger, the poet can employ all possible worlds in her work, because she needs to explore both those parts of creation that are visible and those that are invisible. The marvelous that arises out of presenting the merely possible not only retains readers' attention and creates delight, but also opens the literary work to elements of the world that might not be perceptible to the naked eye. It elicits a profitable struggle with our reason:

Sobald ein Ding, das das Zeugniß der Wahrheit oder Möglichkeit hat, mit unsren gewöhnlichen Begriffen zu streiten scheinet, so kann es uns nicht bloß als neu und ungewohnt vorkommen, sondern es wird das Gemüthe in eine angenehme und verwundernsvolle Verwirrung hinreissen, welche daher entspringet, weil wir mit unserm Verstand durch den reizenden Schein der Falschheit durchgedrungen, und in dem vermeinten Widerspruch ein geschicktes Bild der Wahrheit und eine ergezende Übereinstimmung gefunden haben (Breitinger, 1966, pp. 129-30). ${ }^{15}$

Breitinger never cuts the marvelous loose from 'Wahrscheinlichkeit'. Indeed, he writes 'Das Wunderbare ist demnach nichts anders, als ein vermummetes Wahrscheinliches' (Breitinger, 1966, p. 132). ${ }^{16}$ While the poet strives to distance her work from the actual world to a certain degree, the marvelous that emerges needs to be designed in such a fashion that our imagination can train itself in its judgements about probability (Breitinger, 1966, pp. 138, 308-10).

While most other critics writing on the debate between Gottsched, Bodmer and Breitinger stress the (profound) disagreements between the Swiss and the German, it has been

\footnotetext{
13 'Hence the pleasure is two-fold, the first emerges from the subject matter of imitation, the second from its art'.

14 'Accordingly, the newer, the less familiar, the less expected the thought, the more delightful must it be'.

15 'As soon as something that has been confirmed as true or possible seems to conflict with our general concepts, it might seem not just new and unfamiliar, but will pull the mind into a pleasant and marvellous confusion, which emerges because we have penetrated the teasing illusion of falseness with our reason, and have found in the seeming contradiction a well-designed image of truth and a pleasurable correspondence'.

16 'The marvelous is accordingly nothing but masked probability'.
} 
my interest here to work out the common ground from which they started the debate. In each of their takes, the marvelous and the probable are closely connected, and, with shifting emphasis, they acknowledge that both have a role to play in literature. If we phrase a definition of tellability in eighteenth-century terms, drawing on Gottsched, Bodmer and Breitinger, it can run as follows: A narrative becomes tellable by introducing aspects of the marvelous (through unnatural fictional worlds, but also through actions and events in the plot), because it provides a new and unexpected take on this world. At the same time, the marvelous needs to be embedded in the probability of the fictional world so that it can lead readers back to an instructive realization about the real world drawn from the marvelous, and hence remain worth telling.

\section{Upper and Lower Limits of Tellability}

Let us turn to Karolinens Tagebuch to see how such eighteenth-century tellability plays out in the eighteenth-century novel. Karoline's first literary endeavour in her letters to her sister Nanette clearly fails to achieve tellability. 'Wie? Ich wäre nicht klug, sagtest Du gestern zu mir: "mein Geschmiere wär' nicht wert, daß man darauf achtete”' (Karolinens Tagebuch, p. 33). ${ }^{17}$ In the previous letter, Karoline recounts a dinner party in a satirical tone, concluding that none of the behaviours on display could be a model of her own. Nanette, however, does not care for her sister's professed discernment: It is 'nichts als ein eitler Kunstgrif um mir dadurch einiges Lob zu erschleichen' (Karolinens Tagebuch, pp. 33-34). ${ }^{18}$ The dinner party (which Nanette also attended) is profoundly uninteresting, as Karoline herself remarks, and also her satirical comments do not make it worthwhile. By the end of her letter of response to Nanette, however, Karoline has developed a different strategy: 'Doch warte, ich habe schon einen andern Vorrath da: die Fräulein Eleonora Lusani hat mir in einen Aufsatz, ihre eigene Geschichte überschicket. Hievon will ich dir von Zeit zu Zeit einen Theil in Abschrift überschicken, und vielleicht kann ich dich damit angenehmer unterhalten' (Karolinens Tagebuch, p. 40). ${ }^{19}$ In the narrative of Eleonora, which Karoline purports to copy, tellability is much increased. Indeed, we find almost all the features that Ryan introduces in her formula for French fiction: Eleonora encounters a duchess (aristocracy), she narrowly escapes a sexual predator (sex), she is locked away from the rest of world (social death) and she is repeatedly

\footnotetext{
17 'What? I'm not prudent you said to me yesterday: "my scribbling is not worth of being taken note"'. 18 'Nothing but a sleight of hand to garner praise'.

19 'But wait, I already have another store: Miss Eleonora Lusani has sent me an essay, her own history. From this narrative I shall send you parts from time to time, in hope to provide more pleasant entertainment'.
} 
asked to rely on providence (religion). Eleonora describes herself as a 'heroine' ('Romanenheldin', p. 44) and the narrative might put contemporary readers in mind of Christian Fürchtegott Gellert's Geschichte der schwedischen Gräfin von G*** (1746) or Sophie von LaRoche's Geschichte des Fräuleins von Sternheim (1771), where young women are taken out of their safe domestic environments and submitted to the whims of fortune. By introducing elements of the contemporary novel, Karoline has dramatically increased the tellability of her narrative, and Nanette will not interrupt her again.

When Eleonora's narrative draws to a close, Karoline already has new plans: she proposes to compose a novel 'wo etwas mehr von Handlungen zu lesen seyn wird' (Karolinens Tagebuch, p. 256). ${ }^{20}$ She writes:

Ein Paar Helden habe ich schon im Vorrath, die ihre Prinzessinnen von ihren Verfolgern erretten, sie hinter sich auf das Pferd werfen, und mit ihnen ganz tugendhaft in den Wäldern herrumirren, sie hernach verlieren, dreyssig, vierzig Jahre in der Welt herumsuchen, endlich auskundtschaften; aber um selbige blutige Kriege führen müssen, und als Ueberwinder, ihre Heldinnen noch in der blühendesten Schönheit finden, sie heyraten und ganze Jahre mit Banquetiren und Turniren bey der Hochzeit verbringen (Karolinens Tagebuch, p. 256). ${ }^{21}$

If we identify tellability as the new and noteworthy aspects of narrative, then Karoline's forecast of the next planned narrative brings even more tellable elements into play. We have even higher degrees of nobility ('Prinzessinnen'), repeated separation and rescue, a larger scale of conflict ('blutige Kriege'), surprising temporal inconsistencies and excessive splendour at the wedding. And yet we do not have to adopt the stern mind-set of Herr Cyrili to find the narrative that Karoline proposes ridiculous. Because this version of the baroque romance is such a condensed panoply of marvels, it ceases to have any significant degree of tellability.

Narratology usually does not ask whether one can stack a tall tale too high. Rather, following Labov's 'so what?', the focus is on pushing the narrative over the threshold of relevance by making it more tellable. An exception is Neal R. Norrick who, working on oral storytelling, suggests a 'two-sided notion of tellability' (2005) with both an upper and a lower limit. The lower limit corresponds to the familiar notion from Labov, whereas the upper limit is drawn by what Norrick calls the 'propriety' of the exchange. Whenever the narrative gets too personal, intimate and revealing, participants in conversational storytelling might judge it

\footnotetext{
20 '[I]n which one can read more actions'.

21 'I already have a couple of heroes in store. They will save their princesses from pursuers, throw them on their horse, and wander about virtuously in the woods, then lose them, search the world for thirty, forty years, finally spot them, but have to lead bloody wars for them, and as victors, find their heroines in the most radiant beauty, marry them and spend entire years with the banquets and tournaments of the wedding'.
} 
as untellable because the breach of canonicity is too violent. Arguably, such a notion of the upper limit of tellability translates into literary narration and, for example, could be fruitfully applied to the study of trauma narratives. To stay within the period, Samuel Richardson has his heroine Clarissa refer of her rape in fractured prose and in a text set confusingly on the page. The events are so disturbing that they do not bear narration or, indeed, create a narrative of 'transgressive, unwelcome and frightening nature' (Smith and Sparkes, 2008, p. 230, see also Baroni, 2014).

Yet Karoline's proposed novel does not interfere with Norrick's conversationally defined notion of 'propriety'. The heroes and their princesses behave 'ganz tugendhaft', and there is no indication of trauma after the 'blutige Kriege'. The upper limit of tellability is instead set by the structuration of the narrative itself and the possible relationship to readers' reality; in other words, its probability. Karoline does not paint a 'geschicktes Bild der Wahrheit' in Breitinger's sense. Instead, we get multiple heroes and princesses and repeated rescues without any indication of how these events differ from and relate to each other meaningfully, expanded time schemes without any corresponding indication of the weight of the subject matter and comeuppance which seems ridiculously disproportionate to the events that precede it. Each element of the narrative has hyperbolic tellability, but Karoline does not provide us with the structuration that would make the narrative overall tellable.

Karoline sets out in her writings with the expressed purpose to learn how to think in an orderly fashion, and she recruits Nanette and Herr Cyrili to help her (Karolinens Tagebuch, p. 15). After each of the passages which she copies from Eleonora's narrative, Karoline comments on her responses to it (p. 54), she reflects on her own emotions in relation to Eleonora's experience and, at times, continues with the narrative to distract herself from her own emotional involvement (pp. 103-04). Also Eleonora and the duchess understand their own lives in terms of the narrative which they read (in the case of Eleonora, p. 107) or write (in the case of the duchess, p. 137). Sagar writes her novel at a time when not only critics but also practioners of literature strove to provide means for educating readers to think about themselves and their place in society (see Baldwin, 2002, pp. 13-37; von Mücke, 1991; McCarthy, 1984); a development that gave rise to the Bildungsroman (see Saariluoma, 2004). The tellability of Eleonora's narrative depends on how much it contributes to the process of Karoline's mental education, which we read about in her comments on the narrative. In the whimsical follow-up narrative, which Karoline suggests, the marvelous does not seem to be embedded in a probability structure that would allow readers to relate events to their own life. Her narrative, even though it capitalizes on the popular narratives of the seventeenth-century 
novel, does not give any indication of how it could be relatable through the experience of the characters themselves and the constellations of events which happen. While the concern with the educational function of literature is fading after the eighteenth century, the trade-off that emerges from it, between marvelous features that make the narrative tellable and the overall probability of the narrative that ensures that it remains tellable (and relatable), is also today relevant for thinking about tellability.

\section{Event-Based and Character-Based Tellability}

In his entry on the topic in the Living Handbook of Narratology, Raphaël Baroni distinguishes between three aspects of tellability. He emphasizes that tellability can arise from the story level of narrative, the discourse level (and the interactions between the two levels), as well as from contextual parameters. The story level, the bare-bones events of the narrative, can hold interest for readers if its arrangement in the plot moves away from standard scripts of action (see Baroni, 2014 and Bruner, 1991) or if there is a particularly rich forest of alternative paths which the plot could have taken (see Ryan, 1991). The evaluation devices of the speaker (or narrator) on the discourse level also contribute to tellability. The third aspect which Baroni highlights are the 'contextual parameters' of tellability, which include on the one hand the situational feedback between storyteller and listener, and on the other hand, contemporary cultural expectations and genre conventions.

In Karolinens Tagebuch, we find all three aspects renegotiated. Her narrative develops out of Nanette's evaluation in the feedback situation of the epistolary novel, where Karoline and Nanette need to agree on what kind of narrative is worth their joint attention. Eleonora's story then presents us with a very tellable narrative in the eighteenth-century mode, including abductions, hidden family relations and revelatory portraits. Its plot moves away from the standard, real-world scripts of action, according to which young women in the company of her mother are not subject to the preying desires of rakish dukes, but go home to marry a predetermined suitor. In particular critics writing on Sagar's novel in a feminist vein have pointed out that the ideal life of a woman in the eighteenth century should not be tellable at all (see Baldwin, 2002; Jirku, 1993). Karoline herself writes to Nanette on their actual lives, 'O was wird das für eine matte Geschichte von uns beyden werden? Siehe in zwey Zeilen kann man unsere ganze Begebenheiten bringen' (Karolinens Tagebuch, p. 302). ${ }^{22}$ There is clearly a gendered dimension, not only in terms of the kinds of narratives that female narrators are

\footnotetext{
22 'Oh what an insipid narrative will be told of us? Look, one can write it all up in two lines'.
} 
allowed to tell (particularly relevant with respect to oral storytelling, I presume), but also in term of the kinds of adventures that female characters can experience. This gendered dimension prefigures the tellability of female lives, probably according to the prototypical female plots that Nancy Miller (1984) works out for eighteenth-century French and British novels, and gives it standard ways of deviating from the uneventfulness of feminine lives. Karoline's letters, in the feminist take on the novel, are a way for her to write back against the expected 'matte Geschichte' of the normal female life on the one hand (see Baldwin), but also, I think, against the expected conventional modes of female adventures made tellable in the literature of the day.

Karoline's brother Leopold challenges her writing repeatedly and threatens to publish it, which she responds to, first, by recording everything that he says, with unnerving accuracy, into her letters (Karolinens Tagebuch, p. 38), and then by stating that she is not afraid of what improbabilities male critics might discover in her writings (ibid., pp. 197-98). 'Aber dir bleibet immer der Stahr in den Augen, wenn du auch mit jenen glaubtest, daß es, um einen Roman zu schreiben, über die frauenzimmerliche Logik, noch etwas mehreres brauche als Romanen gelesen zu haben' (Karolinens Tagebuch, p. 198). ${ }^{23}$ In the overall composition of Sagar's novel, these two responses are connected: the very detailed recording of Leopold's taunts, and Karoline's own thoughts, as she reflects on Eleonora's narrative and her own situation as bride, stand in opposition to the well-designed narratives of Eleonora and the duchess and the stylized comedic conclusion to the novel (which I shall address in more detail in the next section). Sagar seems to work towards a novel in which the everyday life-events of Karoline gain narrative interest.

In 1774, the same year as Sagar's novel, Friedrich von Blanckenburg publishes his Versuch über den Roman (Essay on the Novel). Blanckenburg operates within the same terminological parameters as Gottsched, Bodmer and Breitinger had thirty years earlier, and he asserts the need for 'probability', but he gives the term a different emphasis than the earlier generation of critics had. Responding to new developments in novel-writing, in particular Wieland's Geschichte des Agathon (The History of Agathon; 1766-1767) and Fielding's Tom Jones (1749), Blanckenburg writes:

Eine andre Folge, die aus dieser Behandlung der Begebenheiten entsteht, ist diese, daß der einzelnen Vorfälle nicht mehr so viel werden seyn können, als bis jetzt in den gewöhnlichen Romanen zusammen gepfropft sind. Der kleinste Vorfall nämlich wird zu seinem Wirklichwerden eine Reihe von Ursachen nöthig haben, die zwar an und

\footnotetext{
23 'But you will always be blind to the truth if you believe that in order to write a novel on female logic you need any other qualifications than having read many novels'.
} 
vor sich selbst auch andere Vorfälle wieder seyn können; diese aber werden sehr oft aus so unmerklich kleinen Zügen bestehen müssen, daß man sie nie unter die Begebenheiten eines Romans wird zählen wollen, wenn man die Begriffe hierzu aus den gewöhnlichen Werken dieser Art nimmt. Daher wird natürlich eine einzige Begebenheit, zu ihrem Wirklichwerden, mehr Raum erfordern, als jetzt zur Erzehlung von zehnen erfordert wird [...] Von dieser Art der Behandlung einer Begebenheit gilt es übrigens im eigentlichen Verstande, dass der Dichter seine Leser zwingen könne, das zu glauben, was er wolle, dass sie glauben sollen [...] Wir sehen, bey dieser Behandlung, die Personen anschauend mit all ihren Eigenthümlichkeiten vor uns. Sie treten gleichsam aus dem Gemälde hervor (Blanckenburg, 1774, pp. 308-10). ${ }^{24}$ What constitutes for Blanckenburg the successful imitation of nature is to have characters so detailed that they 'step out' of the picture of poetic creation, and the tellabilility that he envisages is that of the small events of everyday experience in all its complexity.

Wieland's Geschichte des Agathon, for example, enacts this move. The narrative starts with fast-paced action of the ship-wreck, the Bacchantes, and the slave-traders that capture the hero (all features of the novel of the seventeenth century), but then, as the hero develops his own thinking about the question of the good life and as the narrative perspective gets more complex, the narrative itself slows down. Karolinen's Tagebuch brings this historical shift from the event-based tellability of baroque novel to the character-based tellability of the eighteenth-century novel (which arguably also underlies today's standard of the novel) more explicitly to the fore. Here, we have the detailed description of Karoline's experience as a bride-to-be and her confusion about her own feelings for her fiancé Karl in contrast with the narrative of Eleonora, and more strikingly, with Karoline's own proposal for a new narrative. The baroque novel's tellability depends on plot events and their strikingness as culturally meaningful. In the German-speaking lands, novels like Andreas Heinrich Bucholz' Hercules (1659) and Henrich Anshelm von Ziegler und Klipphausen's Asiatische Banise (1689) were still read when Sagar's novel was published, or they were reedited, such as Anton Ulrich zu Braunschweig-Wolfenbüttel's Aramena (1669-1673/1782-1786). As late as 1797 and 1799, journals publish keys to identify the historical persons behind the characters in Wolfenbüttel's Octavia (1685-1707; see Cholevius, 1866, pp. 293-94). Sagar's readers would have been well-aware of the event-based tellability of the baroque novel that is satirized in Karoline's

\footnotetext{
24 'Another consequence emerging from this treatment of events is the following: the individual events can no longer be as many as so far have been stuffed together in the ordinary novel. For the smallest event will need a whole range of causes to become real; causes which in turn have to be events, and those will very frequently consist of such small features that you cannot number them as the events of a novel if you take the terms from the common works of this genre. Hence a single event will, naturally, take more space to come real as now is necessary to narrate ten of them [...] This treatment of events means (in the actually sense) that the writer can force their readers to believe what he wants them to believe [...] We see in this treatment the characters with all their features before us. It is almost as if they stepped out of the painting'.
} 
proposal for a new narrative. The eighteenth-century novel's tellability, on the other hand, depends more on the responses of characters to these plot events and on their strikingness as an exceptional (but relatable) experience. Even though I cannot offer a detailed historical trajectory from the tellability of the baroque novel to the tellability of the eighteenth-century novel, the juxtaposition of different kinds of tellability in Karolinens Tagebuch illustrates the need for a diachronic investigation of narrative concepts in order to distinguish between different kinds of their instantiation in the long course of the development of narrative fiction.

\section{The Metafictional Dimension of Tellability}

In his essay 'The Narrative Construction of Reality' (1991), the psychologist Jerome Bruner lists nine principles that circumscribe how our minds get a grip on reality through narrative. Narrative, in other words, becomes an intelligent tool through which we make sense of and communicate our world; a take which cognitive narratology has often supported (see Herman 2009). 'Canonicity and breach' is one of Bruner's principles that has been related in particular to tellability (see Ryan, 2005 and Baroni, 2014). According to this principle, the scripts of social actions, such as the moves we go through when visiting a restaurant (a classical example from Schank and Abelson), are 'pointless' and they need to be broken for a narrative to emerge out of conventional, routine actions (Bruner, 1991, p. 11). However, he also stresses that the breaches of canonicity are often conventionalized, and focuses on the case of everyday narrative (and its cognitive functions) rather than on literary texts.

If we turn to the eighteenth-century debates around probability, we quickly come across a concept that shares features with Bruner's principle: 'improbable probability'. Gottsched writes, 'eine Sache, die an sich unglaublich und unmöglich aussieht, durch den Zusammenhang mit anderen Begebenheiten und unter gewissen Umständen nicht nur möglich, sondern auch wahrscheinlich und glaublich werden könne' (Gottsched, 2003, p. 132). ${ }^{25}$ An improbable event can be included in the larger context of the narrative in such a way that it becomes probable after all. Aristotle puts this notion centre-stage in his Poetics: the best, complex plots involve reversals (peripetia) that are unexpected and yet following an inner logic ('as a result of what has happened before, out of necessity or in accordance with probability', p. 18), and hence they create effects of 'astonishment' (Aristotle, 1996, p. 30). For clever people, like Sisyphus, to be deceived in the reversal, says Aristotle, citing the Greek playwright Agathon, '[there] is no violation of probability in this; [...] it is probable for

\footnotetext{
25 '[A] matter, which in and of itself might seem incredible and impossible, [can] in connection with other events and under particular circumstances not only become possible but probable and believable'.
} 
many improbable things to happen' (Aristotle, 1996, p. 30). In his conclusion to the discussion of plot, Aristotle plays through the constellations of the improbable and the probable once more and states that 'it is probable that improbable things will happen' (Aristotle, 1996, p. 45). Improbable things may well happen in a narrative (and make it tellable), but literature then uses these improbabilities to reaffirm the probability of the narrative in an unexpected way (and hence increases the overall tellability of the narrative). David Herman's discussion of Bruner's 'canonicity and breach' (Herman, 2009, p. 19-21) suggests that as the narrative deals with the breach, and redresses the balance, it provides explanations and formulates reasons for readers. The improbable is reinscribed into the probable. However, this account seems to side-line the surprising nature of Aristotelian reversal, as well as the more metafictional solution to improbable probability which the eighteenth century has devised.

In Karolinens Tagebuch, Sagar offers various instances of 'improbable probability' The first revolves around the conclusion to Eleonora's narrative, when Herr Cyrili interrupts Karoline and asks her how she wants to bring the narrative to an end, given all its confusing loose ends ('Sie haben sich ziemlich verwickelt, wie werden sie sich heraus helfen, und wo haben sie alles das Zeug hergenommen?', Karolinens Tagebuch, p. 259). More precisely, how is she going to pay for all the expenses, such as debts accrued and commissions in the army, that she has imposed on her characters ('sie haben sie in erstaunliche Ausgaben versetzt', ibid.)? Karoline proposes to kill off some of the older characters to bring about an inheritance and to have a treasure hidden in the library to be found in good time, but she also states that this very conventional ending has been enforced by Herr Cyrili's lack of patience and that she could have provided a more fitting one on the principle of improbable probability ('Ich hatte meiner Geschichte eine unerwartete Entwicklung zugedacht, sie bringen sich selbst um die Ueberraschung'. Karolinens Tagebuch, p. 263). Sagar here provides a conclusion that would fall flat if it were not for the metafictional framework of Karoline's comments on the narrative that she tells. For Eleonora's narrative, the ending with the found treasure and the double inheritance seems rather too improbable, even within the conventions of the novel. However, because this conclusion emerges from Karoline's reaction to Cyrili's impatience, it works within the probabilities of the frame narration. It is a surprising ending, but one that Karoline would probably devise, given the situation.

In many eighteenth-century novels, improbable probability is included, and tellability is ensured, though such a metafictional shift of probability across narratorial levels. Rüdiger Campe in his book The Game of Probability (2012) connects the critical debates around 
poetic probability in the eighteenth century to debates around probability calculus. In the chapter on 'Improbable Probability', he discusses Fielding's Tom Jones and Wieland's Geschichte des Agathon for the ways in which they splice probability through a double narrative frame. According to Campe, Fielding's and Wieland's reader is presented with a 'world whose probability he can supply because he understands the improbability of its constitution' (Campe, 2012, p. 292). This framing device, so Campe, becomes 'necessary for [the novel's] own functioning' (Campe, 2012, p. 290) and turns improbable probability into the 'hallmark of the theory of the novel' (Campe, 2012, p. 284).

In the case of Eleonora's narrative, however, we as readers do not exactly supply probability for this narrative once we understand its improbability. Rather, Sagar seems to use Eleonora's narrative to guide readers' attention to another instance in which improbable probability works as it should. This other instance is the frame narrative of Karoline's and Karl's courtship. Throughout the novel, Karoline struggles with understanding the feelings that she has for Karl (see Karolinens Tagebuch, pp. 79, 81, 102). She chooses to approach him through the fictional templates of the dramatic performance, obviously contrived but highly effective in Sagar's novel. When Karl declares his feelings, Karoline cannot respond in any other way than by asking her brother to tell her which role in this 'comedy' she is supposed to play (p. 98). Elsewhere, she similarly understands their relationship as a piece for the theatre for the benefit of her relatives ('Schauspiel', p. 144) and describes her suitor in terms of theatrical protagonists (pp. 274-75). When Karl is seriously ill, Karoline expects, like a sentimental heroine, that seeing her will contribute to his recovery - and indeed, it does. Sagar foregrounds the improbable probability further, when she writes the scene in which Karoline confesses that she loves Karl and agrees to marry him as a dialogue in a play.

The frame narrative of Karolinens Tagebuch gains tellability, not so much because the events of the courtship would be terribly interesting, but because Sagar makes their constructedness salient in the metafictional shift in improbable probability. By foregrounding the conventionality of its narrative, Sagar's novel (and many other eighteenth-century narratives with a metafictional slant) turns Bruner's principle upside-down. Sagar does not rely on breaking canonicity. Rather, as she foregrounds the canonical modes of telling a narrative like Karoline's, Sagar makes the narrative tellable. To my knowledge, narratologists working on tellability have not considered how the concept plays out in metafictional texts. From the eighteenth-century perspective, improbable probability suggests that tellability can emerge from surprising, yet fitting plot solutions and from foregrounding the very fittedness of a convention metafictionally. 


\section{Conclusion}

Bruner writes, 'Labov's great credit is to have recognized that narrative structures have two components: "what happened and why it is worth telling"' (Bruner, 1991, p. 12; cited in Baroni, 2014). As Baroni points out, the second question is side-lined by the structuralist approaches to narratology that consider mostly how a narrative is constituted and not why one might want to share it or hear it. Structuralist abstraction is certainly a good explanation for why it was sociolinguistics, and its interest in situated storytelling, that introduced the concept of tellability into narratology. At the same time, it seems that the general notions of literary appreciation are not entirely favourable to notions of 'tellability' either. As indicated by Flaubert's comments on Madame Bovary, tellability smacks of narratives with a need to be heard, narratives that follow a purpose, and narratives that strive to please readers rather than ascend to heights of artistic disinterestedness that became more prominent in the nineteenth century. Hence, it seems not surprising that tellability has not been developed with literary narratives in mind. Eighteenth-century literary criticism provides us with a reservoir of critical voices and conceptual developments that takes us not only back in time before the current conventions of literary appreciation were institutionalized but that also allows us to step outside these conventions when discussing narrative concepts.

Eighteenth-century quixotes generally awaits a better fate than Madame Bovary, because the Enlightenment believes more strongly in the educational capacities of literature. Literary templates allow Karoline to come to terms with her feelings for Karl. In Wieland's Don Sylvio, a narrative 'wo alles wunderbare natürlich zugeht' (as the subtitle informs readers), ${ }^{26}$ the hero seems to enter a fairy realm only to find out that the adventures were designed to educate him out of his delusions. Literature does not just take readers' minds away from reality, and achieves tellability because it is new and special, but also because it can help readers find a new relationship to the social and cultural worlds that they live in, and achieve tellability because it provides an important insight to be gained. Narratives like Sagar's (and Wieland's) were written in close conversation with contemporary criticism and work through such tensions in tellability. They shuttle between the lower and the upper limits of tellability, they trace a development between (historically) different kinds of tellability and they renegotiate canonicity and breach by drawing attention to the metafictional aspects of tellability. Even if we do not want to go back to eighteenth-century ideas about literature that

\footnotetext{
26 '[W]here everything marvelous is achieved by nature'.
} 
instructs and delights, we can still use their different perspective on narrative to develop our own, present-day perspective.

\section{Works Cited}

Aristotle. 1996. Poetics. Trans. by Malcolm Heath. Harmondsworth: Penguin Books.

von Blankenburg, Christian Friedrich. 1774. Versuch über den Roman. Leipzig and Liegnitz. Available through Bodleian Libraries Oxford, dbooks.

Baldwin, Claire. 2002. The Emergence of the Modern German Novel: Christoph Martin Wieland, Sophie von La Roche, and Maria Anna Sagar. Rochester: Camden House.

Baroni, Raphaël. 2009. L'oeuvre du temps. Poétique de la discordance narrative. Paris: Seuil.

Baroni, Raphaël. 2014. 'Tellability'. The Living Handbook of Narratology, ed. by Peter Hühn et al. Hamburg: Hamburg University. Last accessed 01 Dec 2014.

Bender, Wolfgang. 1973. J.J. Bodmer und J.J. Breitinger. Stuttgart: Metzler.

Bodmer, Johann Jakob. 1996. Kritische Abhandlung von dem Wunderbaren in der Poesie (1740). Stuttgart: Metzler, 1996.

Bray, René. 1927. La formation de la doctrine classique en France. Paris: Hachet.

Breitinger, Johann Jakob. 1966. Kritische Dichtkunst (1740). Erster Band. Stuttgart: Metzler.

Brown, Hilary. 2012. Luise Gottsched the Translator. Rochester, NY: Camden House.

Bruner, Jerome. 1991. 'The Narrative Construction of Reality'. Critical Inquiry 18.1: pp. 121.

Campe, Rüdiger. 2012. The Game of Probability: Literature and Calculation from Pascal to Kleist. Stanford: Stanford University Press.

Cholevius, Leo. 1866. Die bedeutendsten deutschen Romane des 17. Jahrhunderts: Ein Beitrag zur Geschichte der deutschen Literatur. Leipzig. Available through hathitrust.

Doležel, Lubomìr. 1990. Occidental Poetics: Tradition and Progress. Lincoln and London: University of Nebraska Press.

Fludernik, Monika. 1996. Toward a 'Natural' Narratology. London: Routledge.

Goodman, Katherine. 2005. 'Gottsched's Literary Reforms: The Beginning of Modern German Literature'. German Literature of the Eighteenth Century: The Enlightenment and Sensibility, ed. by Barbara Becker-Cantarino. Rochester: Camden House. pp. 55-78.

Gottsched, Johann Christoph. 2003. 'Versuch einer Kritischen Dichtkunst'. Schriften zu Literatur, ed. by Horst Steinmetz. Stuttgart: Reclam.

Hagstrum, Jean H. 1968. Sister Arts: The Tradition of Literary Pictorialism and English Poetry from Dryden to Gray. Chicago: University of Chicago Press. 
Herman, David. 2009. Basic Elements of Narrative. Oxford: Wiley Blackwell.

Jirku, Brigitte E. 1993. 'Spiel, Spiegel, Schrift in Maria Anna Sagars Karolinens Tagebuch'. Colloquia germanica 26.1: pp. 17-35.

Kowalik, Jill Anne. 1992. The Poetics of Historical Perspectivism: Breitinger's Critische Dichtkunst and the Neoclassical Tradition. Chapel Hill and London: The University of North Carolina Press.

Kremer, Natalie. 2011. Vraisemblance et représentation au XVIIIe siècle. Paris: Honoré Champion.

Kukkonen, Karin. 2014. 'Bayesian Narrative: Probability, Plot and the Shape of the Fictional World'. Anglia: Journal of English Philology 132.4: pp. 720-39.

Kukkonen, Karin. 2015. 'Continental Models of Criticism'. The Encyclopedia of British Literature 1660-1789, ed. by Gary Day and Jack Lynch. Oxford: Wiley Blackwell: pp. 30709.

Labov, William. 1972. Language in the Inner City: Studies in the Black English Vernacular. Philadelphia: University of Pennsylvannia Press.

Lorenz, Sarah Ruth. 2014. 'Shifting Forms of Mimesis in Johann Christoph Gottsched's Dichtkunst'. The German Quarterly 87.1: pp. 86-107.

McCarthy, John A. 1984. 'The Art of Reading and the Goals of the German Enlightenment'. Lessing Yearbook 16: pp. 79-94.

Miller, Nancy. 1984. The Heroine's Text: Readings in French and English Literature, 17221782. New York: Columbia University Press.

von Mücke, Dorothea. 1991. Virtue and Veil of Illusion: Generic Innovations and the Pedagogical Project in Eighteenth-Century Literature. Stanford: Stanford University Press.

Norrick, Neal R. 2005. 'The Dark Side of Tellability'. Narrative Inquiry 15.2: pp. 323-42.

Ochs, Elinor and Lisa Capps. 2001. Living Narrative: Creating Lives in Everyday Storytelling. Cambridge: Cambridge University Press.

Patey, Douglas Lane. 1984. Probability and Literary Form: Philosophical Theory and Literary Practice in the Augustan Age. Cambridge: Cambridge University Press.

Pratt, Mary Louise. 1977. Toward a Speech Act Theory of Literary Discourse. Bloomington: Indiana University Press.

Ryan, Marie-Laure. 1991. Possible Worlds, Artificial Intelligence and Narrative Theory. Bloomington: University of Indiana Press.

Ryan, Marie-Laure. 2005. 'Tellability'. The Routledge Encyclopedia of Narrative, ed. by David Herman, Marie-Laure Ryan, and Manfred Jahn. London: Routledge. pp. 589-91.

Saariluoma, Liisa. 2004. Erzählstruktur und Bildungsroman: Wielands Geschichte des Agathon und Goethes Wilhelm Meister. Würzburg: Königshausen und Neumann.

Sagar, Maria Anna. 2013. Karolinens Tagebuch, ohne ausserordentliche Handlungen oder 
gerade so viel als gar keine. Hildesheim.

Smith, Brett and Andrew Sparkes. 2008. 'Changing Bodies, Changing Narratives and the Consequences of Tellability: A Case Study of Being Disabled Through Sport'. Sociology of Health and Illness 30.2: pp. 217-36.

Voltaire. 1820. La Henriade, suivi par l'essai sur la poésie épique. Paris. Available through BNF, gallica.

Wieland, Christoph Martin. 2008. Geschichte des Agathon. Stuttgart: Reclam.

Zelle, Carsten. 2009. “"Vernünftige Gedanken der Beredsamkeit” - Bodermes und Breitingers ästhetische Schriften und Literaturkritik'. Bodmer und Breitinger im Netzwerk der europäischen Aufklärung. Ed. by Anett Lütteken and Barbara Mahlmann-Bauer. Göttingen: Wallstein. pp. 25-41. 